\title{
The anti-inflammatory activity of standard aqueous stem bark extract of Mangifera indica $L$. as evident in inhibition of Group IA sPLA
}

\author{
BHADRAPURA LAKKAPPA DHANANJAYA ${ }^{1,2}$ and SUDHARSHAN SHIVALINGAIAH ${ }^{1}$ \\ ${ }^{1}$ Venom Research Unit, Adichunchanagiri Biotechnology and Cancer Research Institute (ABCRI), \\ Balagangadharanatha Nagara, Mandya District, Karnataka 571 448, India \\ ${ }^{2}$ Toxinology/Toxicology and Drug Discovery Unit, Center for Emerging Technologies, Jain Global \\ Campus, Jain University, Kanakapura Taluk, Ramanagara-562112, Karnataka, India
}

Manuscript received on December 18, 2014; accepted for publication on April 3, 2015

\begin{abstract}
The standard aqueous stem bark extract is consumed as herbal drink and used in the pharmaceutical formulations to treat patients suffering from various disease conditions in Cuba. This study was carried out to evaluate the modulatory effect of standard aqueous bark extract of $M$. indica on Group IA sPLA 2 . $M$. indica extract, dose dependently inhibited the GIA sPLA $\left(\mathrm{NN}_{2} \mathrm{XIa}-\mathrm{PLA}_{2}\right)$ activity with an $\mathrm{IC}_{50}$ value $8.1 \mu \mathrm{g} / \mathrm{ml}$. $M$. indica extract effectively inhibited the indirect hemolytic activity up to $98 \%$ at $\sim 40 \mu \mathrm{g} /$ $\mathrm{ml}$ concentration and at various concentrations $(0-50 \mu \mathrm{g} / \mathrm{ml})$, it dose dependently inhibited the edema formation. When examined as a function of increased substrate and calcium concentration, there was no relieve of inhibitory effect on the GIA sPLA . Furthermore, the inhibition was irreversible as evidenced from binding studies. It is observed that the aqueous extract of $M$. indica effectively inhibits SPLA $_{2}$ and it is associated inflammatory activities, which substantiate their anti-inflammatory properties. The mode of inhibition could be due to direct interaction of components present in the extract, with sPLA $\mathrm{A}_{2}$ enzyme. Further studies on understanding the principal constituents, responsible for the anti-inflammatory activity would be interesting to develop this into potent anti-inflammatory agent.
\end{abstract}

Key words: secretory phospholipase $\mathrm{A}_{2}$, anti-inflammatory, pro-inflammatory, inhibition, drug, plants.

\section{INTRODUCTION}

Phospholipases $\mathrm{A}_{2}\left(\mathrm{PLA}_{2}\right)\left(\mathrm{PLA}_{2}, \mathrm{EC}\right.$ 3.1.1.1.4) are a family of key enzymes, that cleaves fatty acids at the $s n-2$ position of glycerol phospholipids to liberate free fatty acid and lysophospholipid (Nanda et al. 2007, Burke and Dennis 2009). The released free fatty acid i.e., arachidonic acid, is known to liberate potent and short-lived pro-

Correspondence to: Bhadrapura Lakkappa Dhananjaya

E-mail: chandu_greeshma@rediffmail.com inflammatory mediators such as prostaglandins, thromboxanes, prostacyclins and leukotrienes; by the action of cyclooxygenase (COX) and lipooxygenase (LOX) (Nanda et al. 2007, Vadas and Pruzanski 1984, Diaz and Arm 2003). The other sPLA $_{2}$ action product -lysophospholipid that is liberated has also been demostrated to serve as a substrate for the synthesis of pro-inflammatory platelet activating factors (PAF) (Burke and Dennis 2009, Diaz and Arm 2003). Thus, it can be concluded that the release of archidonic acid 
from membrane lipids is the first regulatory and obligatory step in the synthesis of pro-inflammatory mediators in inflammatory. This arachidonic acid metabolic pathway is known to be regulated mainly by secretory phospholipase $A_{2}$, suggesting the importance of enzyme in inflammation related processes (Nanda et al. 2007). In snake venoms, only two groups of sPLA $_{2} \mathrm{~s}$ (GI and GII) have been identified. Group I (GIA) includes the svPLA 2 from Elapinae and Hydrophiinae venoms with 115-120 amino acid residues and these svPLA 2 are homologous to mammalian pancreatic GIB sPLA $_{2}$. Group II (GIIA and GIIB) comprises the $\mathrm{svPLA}_{2} \mathrm{~s}$ from Crotalinae and Viperinae venoms with 120-125 amino acid residues and homologous to mammalian non-pancreatic Group II-A sPLA (Burke and Dennis 2009). Group II PLA 2 s are in turn divided into different subgroups on the basis of amino acid residue in the $49^{\text {th }}$ position: catalytically active D49 enzymes, catalytically inactive or with low activity K49, S49, N49 or R49 forms (Nevalainen et al. 2012, Lomonte et al. 2009). The subgroups described above exhibit a wide variety of physiological and pathological effects including the inflammatory one (Doley et al. 2010, Kini 2003).

An increased level of sPLA $_{2}$ are found in inflammatory exudates such as synovial fluid, pleural fluid, ascitis fluid (Bomalaski and Clark 1993) and also in plasma after an inflammatory challenge (Wright et al. 1990). In addition, an excess level of $\operatorname{sPLA}_{2} \mathrm{~s}$ is found to be associated with many physiopathological processes such as in cerebral illnesses, cardiovascular disorders, cancers, asthma, respiratory distress syndrome, and progression of tonsillitis (Mallat et al. 2010, de Luca et al. 2011, Chalbot et al. 2011, Farooqui et al. 1999). Furthermore, an increased level of sPLA activity is also observed in some brain tumors, in chronic neurological disorders associated with neurodegenerative diseases such as neural trauma, Alzheimer's, and Parkinson's diseases (Farooqui et al. 1999, Sun et al. 2004). Several studies have demonstrated that the $\mathrm{SPA}_{2}$ inhibitors suppress inflammatory processes, which provides a strong evidence for their role in pathogenesis in inflammation (Nanda et al. 2007, Moses et al. 2006, Balsinde et al. 1999, Granata et al. 2003, Kim et al. 2004, Rosenson et al. 2010). It has been observed that effective inhibitors of PLA $_{2}$ are known to suppress the inflammation and its associated aspects (Nanda et al. 2007, Meyer et al. 2005, Narendra Sharath Chandra et al. 2007). Considering the role of $\mathrm{sPLA}_{2} \mathrm{~s}$ in the inflammatory process, there is considerable pharmacological interest in finding

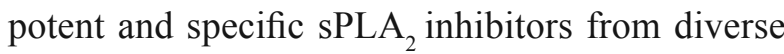
sources (Nanda et al. 2007, Narendra Sharath Chandra et al. 2007). In addition, considering the drawbacks and severe side effects exhibited by the current anti-inflammatory therapies (non-steroidal anti-inflammatory drugs) targets either LOX or COX-1/2 enzymes (Vane and Botting 1998), Therefore, it appears rational to develop or find effective inhibitors of sPLA $_{2}$ which could deplete the downstream pro-inflammatory metabolites of arachidonic acid as well as PAF. Many plant extracts and its constituents are reported for their antiinflammatory activity through inhibition of $\mathrm{SLA}_{2} \mathrm{~s}$ (Nanda et al. 2007, Narendra Sharath Chandra et al. 2007, Springer 2001); effective and specific inhibitors of sPLA $_{2}$ are not available to date. Many studies have shown that sLA $_{2}$ s (of Group I) have a very definite role in pathogenesis of inflammation (Granata et al. 2003, Kim et al. 2004, Rosenson et al. 2010), therefore, it would be beneficial to find plant extract/compounds exhibiting inhibitory activity against group I sPLA ${ }_{2}$, this would be of potential therapeutic relevance in many inflammatory diseased state (Scott et al. 2010, Dessì et al. 2013, Magrioti and Kokotos 2013, Slesser et al. 2013).

Mangifera indica L. (Anacardiaceae), also known as mango, aam, grows in the tropical and sub tropical regions and is one of the most popular edible fruit yielding trees in the world. $M$. indica has been traditionally used to treat various diseases 
(Chopra et al. 1956, Coe and Anderson 1996, Shah et al. 2010, Dhananjaya et al. 2011). The aqueous stem bark extract of $M$. indica obtained by decoction has been traditionally used for the treatment of menorrhagia, scabies, diarrhea, syphilis, deabetes, cutaneous infections and anemia, as reported in the Naprolert database (Coe and Anderson 1996, Shah et al. 2010). This standard aqueous stem bark extract has been used in pharmaceutical formulations in Cuba under the brand name VIMANG ${ }^{\circledR}$, to treat patients suffering from increased stress (Guevara et al. 1998). Pharmacological studies have indicated that VIMANG ${ }^{\circledR}$ has immunomodulatory, analgestic, antinociceptive, antioxidant and antiinflammatory effects (Makare et al. 2001, Garrido et al. 2004). Previously, the standard aqueous extract was demonstrated to inhibit the edema induced by carrageen and formalin in mice, rats and guinea-pigs (Garrido et al. 2001, Ojewole 2005). Even though, $M$. indica extract is known to possess anti-inflammatory activities, no study has been conducted with regard to $\mathrm{SPLA}_{2}$ enzyme (main regulatory enzyme in arachidonic acid pathway) inhibition in support of its anti-inflammatory effects. Therefore, in this study, for the first time we report the investigations carried out to evaluate the modulatory effect of standard aqueous extract of $M$. indica on Group IA sPLA 2 (i.e., purified NN-XIa$\mathrm{PLA}_{2}$ phospholipase $\mathrm{A}_{2}$ enzyme from Naja naja venom), to substantiate their anti-inflammatory properties. Furthermore, this study provides an insight on the possible biochemical interaction of extract/components to bring about inhibition of $\mathrm{sPLA}_{2} \mathrm{~s}$ and its inflammatory process.

\section{MATERIALS AND METHODS}

Venom of Naja naja (Indian Cobra) was purchased from Irula Co-operative Society Ltd., Chennai, India. All other reagents and chemicals used were of all analytical grades purchased from Sisco Research Laboratories (SRL), Bangalore, India.
PREPARATION OF EXTRACT

Mangifera indica stem bark collected in the campus of the university, which was authenticated at the university herbarium centre, Department of Botany, University of Mysore, Mysore, India, where a voucher specimen (UOM/DOSB/PL/82) was deposited. The stem bark extract of $M$. indica was prepared by decoction for $1 \mathrm{~h}$ in accordance to the method of Garrido et al. (2004) as described earlier (Dhananjaya et al. 2011)! The fine brown powder obtained after desiccation was dissolved in saline for neutralization assays. The amount of extract is expressed as dry weight.

ANIMALS

Swiss Wistar albino mice weighing about 20-25 $\mathrm{g}$ were obtained from the central animal house facility. All protocols of animal experiments were approved by the Sri Adichunchangiri College of Pharmacy- Institutional Animal Care and Use Committee (IACUC). Animal care and handling were conducted in compliance with the national regulations for animal research.

ISOLATION OF GROUP IA SECRETARY PHOSPHOLIPASE $\mathrm{A}_{2}$ (NN-XIa-PLA ${ }_{2}$ )

sPLA $_{2}$ belonging to the group IA- NN-XIa-PLA from the venom of Naja naja (Southern region) was purified up to homogeneity as described previously by the method of Rudrammaji and Gowda (1998). This protein was further used for evaluating the anti-inflammatory potential of aqueous extract of $M$. indica. The protein concentration was estimated according to the method of Lowry et al. (1951) using BSA as protein standard.

INHIBITION OF PHOSPHOLIPASE A 2 ACTIVITY

The Phospholipase $A_{2}$ assay was carried out according to the method described by Bhat and Gowda (1989). Phosphatidyl choline (PC) was diluted with petroleum ether $\left(60-80{ }^{\circ} \mathrm{C}\right)$ to a 
concentration of $1000 \mathrm{nmoles} / 50 \mathrm{ml}$. The reaction mixture containing NN-XIa-PLA $2(5 \mu \mathrm{g})$ was made up to $680 \mathrm{ml}$ with water. To the reaction mixture, 200 $\mu \mathrm{l}$ of ether, $100 \mu \mathrm{l}$ of Tris $-\mathrm{HCl}$ buffer $(0.05 \mathrm{M}, \mathrm{pH}$ 7.5), and $20 \mu \mathrm{l}$ of $\mathrm{CaCl}_{2}(500 \mathrm{mM})$ was added. The total reaction mixture was incubated at $37{ }^{\circ} \mathrm{C}$ for $60 \mathrm{~min}$. After incubation, $0.5 \mathrm{ml}$ of Doles mixture (Isopropanol: Pet ether: $1 \mathrm{NH}_{2} \mathrm{SO}_{4}, 40: 10: 1$ ) was added, mixed and centrifuged at $1000 \mathrm{rpm}$ for $3 \mathrm{~min}$. To the organic phase $0.5 \mathrm{ml}$ of $\mathrm{CHCl}_{3}$ : Pet ether (1:5) was added, mixed and centrifuged at $1000 \mathrm{rpm}$ for $3 \mathrm{~min}$. To the upper phase cobalt reagent [1.35 vol. of Triethanolamine made up to $10 \mathrm{ml}$ with solution A $\left(6 \mathrm{~g}\right.$ of $\mathrm{CO}\left(\mathrm{NO}_{3}\right) 2$.- $6 \mathrm{H}_{2} \mathrm{O}+0.8 \mathrm{ml}$ glacial acetic acid) and $7 \mathrm{ml}$ of solution $\mathrm{B}$ (Saturated $\mathrm{Na}_{2} \mathrm{SO}_{4}$ )] was added, mixed and centrifuged at $1000 \mathrm{rpm}$ for $3 \mathrm{~min}$. The upper organic phase was carefully transferred and $0.75 \mathrm{ml}$ of a-nitroso-b-naphthol reagent ( $0.4 \%$ a-nitroso-b-naphthol in $96 \%$ ethanol) was added. The intensity of the orange colour is directly proportional to the amount of cobalt present. After $30 \mathrm{~min} 2 \mathrm{ml}$ of ethanol was added to dilute the contents and absorbance was read at $540 \mathrm{~nm}$. The amount of free fatty acid released was estimated using the standard linolenic acid curve. Enzyme activity was expressed as nmol of fatty acid released $/ \mathrm{min} / \mathrm{mg}$ of protein.

For inhibition studies, NN-XIa-PLA 2 (5 $\mu \mathrm{g})$ was preincubated with or without different concentrations of aqueous extract of $M$. indica ( 0 - $20 \mu \mathrm{g} / \mathrm{ml}$ ) at $37{ }^{\circ} \mathrm{C}$ for 15 minutes. Appropriate controls were carried out and further experiments were conducted as described above. The inhibition is expressed as percentage (\%) taking activity of venom alone as $100 \% . \mathrm{IC}_{50}$ values were calculated using Graphpad version 5.0.

EFFECT OF SUBSTRATE AND CALCIUM CONCENTRATION ON NN-XIa-PLA 2 INHIBITION BY AQUEOUS EXTRACT OF M. Indica

Effects of substrate and calcium concentrations on the inhibition of NN-XIa-PLA $2(5 \mu \mathrm{g})$ at $\mathrm{IC}_{50}$ concentration of extract were determined. In general, the reaction mixture containing NN-XIa$\mathrm{PLA}_{2}$ alone and/or with the $\mathrm{IC}_{50}$ concentration of aqueous extract of $M$. indica, in $0.05 \mathrm{M}$ Tris- $\mathrm{HCl}$ buffer, $\mathrm{pH} 7.5$, and $400 \mathrm{mM}$ calcium was used for the $\mathrm{PLA}_{2}$ assay. In the substrate-dependent assay, substrate concentration in the range of 20 to 120 $\mathrm{nM}$ was used as in the final reaction mixture. The calcium-dependent assay was carried out with concentrations ranging from 0 to $15 \mathrm{mM}$ in the final reaction mixture. After the reaction time, $\mathrm{PLA}_{2}$ assay was carried out as described above.

DETERMINATION OF BINDING CHARACTERISTICS AND REVERSIBILITY OF INHIBITION BY $M$. Indica

The reaction mixture containing NN-XIa-PLA 2 (5 $\mu \mathrm{g})$ with the $\mathrm{IC}_{50}$ concentration of aqueous extract of $M$. indica in $0.05 \mathrm{M}$ Tris- $\mathrm{HCl}$ buffer, $\mathrm{pH} 7.5$, and $40 \mathrm{mM}$ calcium were pre-incubated for 15 min. Following the reaction mixture was dialyzed against $1000 \mathrm{ml}$ of $100 \mathrm{mM}$ Tris-HCl buffer, $\mathrm{pH} 7.5$, containing $0.2 \mathrm{mM} \mathrm{Ca}$ at $4{ }^{\circ} \mathrm{C}$ in dialysis tubing (with a molecular weight cut off of 3000-6000) for $24 \mathrm{~h}$ with three buffer changes. The $\mathrm{PLA}_{2}$ activity was assayed before and after dialysis as described above.

\section{NEUTRALIZATION OF INDIRECT HEMOLYTIC ACTIVITY}

Indirect hemolytic activity was assayed as described by Boman and Kaletta (1957). The substrate for the indirect hemolytic assay was prepared by suspending $1 \mathrm{ml}$ of packed fresh human red blood cells and $1 \mathrm{ml}$ fresh hen's egg yolk in $8 \mathrm{ml}$ of phosphate buffered saline (PBS). Aqueous extract of $M$. indica $(0-40 \mu \mathrm{g} / \mathrm{ml})$ was pre-incubated with or without NN-XIa-PLA $2(4 \mu \mathrm{g})$, which showed $100 \%$ hemolytic activity, for $30 \mathrm{~min}$ at $37^{\circ} \mathrm{C}$. To the pre-incubated sample, $1 \mathrm{ml}$ of substrate was added and allowed to react for $45 \mathrm{~min}$ at $37^{\circ} \mathrm{C}$. The reaction was stopped by adding $9 \mathrm{ml}$ of ice-cold PBS. The suspension was mixed and centrifuged at 
$1500 \times \mathrm{g}$ for $20 \mathrm{~min}$. The released hemoglobin was read at $530 \mathrm{~nm}$. A sample with venom alone served as positive control. The hydrolysis of erythrocyte caused by the addition of $9 \mathrm{ml}$ of distilled water is taken as $100 \%$ hydrolysis. Appropriate controls were carried out and the inhibition is expressed as percentage (\%). Values are presented as the mean of 4 independent determinations.

\section{NEUTRALIZATION OF EDEMA INDUCING ACTIVITY}

The procedure of Yamakawa and Hokama (1976) as modified by Vishwanath et al. (1987) was followed. NN-XIa-PLA $2(6 \mu \mathrm{g})$ was preincubated without and/or with different concentration of aqueous extract of $M$. indica $(0-50 \mu \mathrm{g} / \mathrm{ml})$ in a total volume of $20 \mu \mathrm{l}$ saline. The reaction mixture was injected into intra plantar surface of the right hind footpad of mice weighing 20-25 g. The left footpad that received $20 \mu \mathrm{l}$ of saline served as control. After $45 \mathrm{~min}$ the mice were sacrificed giving anaesthesia (Pentobarbitone, $30 \mathrm{mg} / \mathrm{kg}$, i.p.) and both hind limbs were removed at the ankle joint and weighed individually. The increase in weight due to edema is expressed as the ratio of the weight of oedematous limb to the weight of normal (sham injected) limb x 100. Minimum edema dose is defined as the microgram of protein causing an edema ratio of $120 \%$. Injecting a fixed dose of protein into footpads of mice and sacrificing them at regular periods of time, provided time-course curve of edema inducing activity. Edema ratio was calculated and expressed as $\%$.

\section{STATISTICAL ANALYSES}

The $\mathrm{IC}_{50}$ values were calculated using Graph Pad version 5.0. Inhibition percentages were calculated from the difference between inhibitor-treated group and control animals, which received the vehicle. Student's $t$-test for comparisons of unpaired data was used for statistical evaluation.

\section{RESULTS AND DISCUSSION}

sPLA $_{2}$ are groups of enzymes that are the main regulating enzymes in arachidonic acid pathwayderived pro-inflammatory mediators release, and thus play an important role in inflammatory processes (Nanda et al. 2007, Vadas and Pruzanski 1984). Considering the drawbacks and the severe side effects exhibited by current anti-inflammatory therapies that include the non-steroidal antiinflammatory drugs that inhibit either of the LOX or COX-1/2 enzymes (Vane and Botting 1998). It appears rational to develop effective inhibitors of sPLA $_{2}$ that could deplete the downstream proinflammatory metabolites of arachidonic acid as well as PAF (Nanda et al. 2007). It has been observed that effective inhibitors of $\mathrm{sPLA}_{2}$ are known to suppress the inflammation and its associated process (Nanda et al. 2007), thus there is renound interest among the researchers around the world for the search of new potent and specific $\mathrm{SPLA}_{2}$ inhibitors from different sources. Many $\mathrm{SPLA}_{2}$ inhibitors have been isolated from various medicinal plants (Nanda et al. 2007, Narendra Sharath Chandra et al. 2007, Springer 2001), however, effective and specific inhibitors of $\mathrm{SPLA}_{2}$ are still not available. In these line of studies, the aqueous steam bark extract of $M$. indica is evaluated for its antiinflammatory potential by inhibiting inflammatory phospholipase $\mathrm{A}_{2}\left(\mathrm{PLA}_{2}\right)$ belonging to group IA i.e., NN-XIa-PLA ${ }_{2}$, which is isolated from Naja naja venom as per the previously described method of Rudrammaji and Gowda (1989). The ${ }_{\text {PLA }}$ belonging to group IA i.e., NN-XIa-PLA 2 gave a specific activity of around $183.6 \pm 4.6$, when measured using PC as substrate (Table I). When preincubated with different concentrations of extract it was observed that the aqueous extract of $M$. indica, inhibited the enzymatic activity in a concentration dependent manner as shown in Fig. 1. The result shows that the extent of inhibition was $>95 \%$ at $40 \mu \mathrm{g} / \mathrm{ml}$ of extract used. The $\mathrm{IC}_{50}$ values 


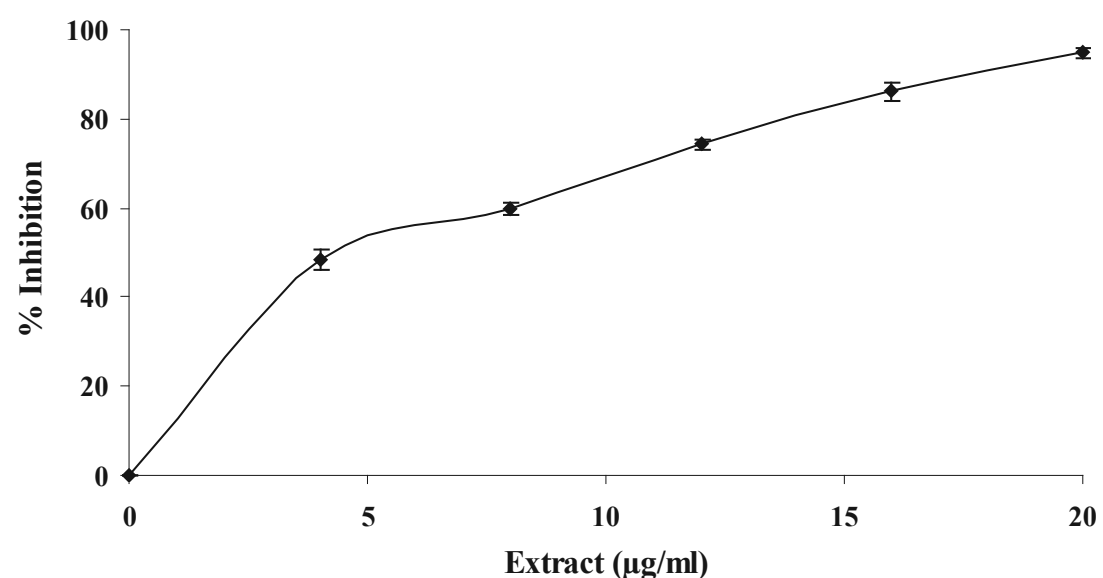

Figure 1 - Dose dependent inhibition of in vitro PLA (NN-XIa-PLA $_{2}$ ) activity by aqueous stem bark extract of $\boldsymbol{M}$. indica. Briefly, Phosphatidyl choline (PC) corresponding to $1000 \mathrm{nmol} / \mathrm{ml}$ was made up to $680 \mu 1$ with NN-XIa-PLA 2 (5 $\mu \mathrm{g})$, with or without aqueous stem bark extract of $M$. indica at various concentrations $(0-20$ $\mu \mathrm{g} / \mathrm{ml}$ ) and was incubated with other reaction mixture at $37^{\circ} \mathrm{C}$ for $60 \mathrm{~min}$ and color developed was read at $540 \mathrm{~nm}$. The results show \pm S.E.M. for $\mathrm{n}=3$.

calculated was $8.1 \mu \mathrm{g} / \mathrm{ml}$ (Table I). Most of the $\mathrm{SPLA}_{2}$ inhibitors are known to inhibit the activity either by binding to substrate or by chelating calcium, which is required for activity (Nanda et al. 2007). Furthermore, it was observed that the $\mathrm{sPLA}_{2}$ inhibitors affect the "Quality of interface" by modifying the phospholipids bilayer properties which render the phospholipids inaccessible to the enzyme. The steroid inducible inhibitors of $\mathrm{sPLA}_{2}$ like lipocartin I and II are shown to inhibit by nonspecific binding to the membrane phospholipids. It is also observed that their inhibition is relieved by increasing the substrate concentration (Davidson et al. 1987). In our experiments, we observed that, when examined as a function of substrate concentration, there was no relieve of inhibition of the extract preincubated, and also when the substrate concentration was increased from 20 to

TABLE I

$\mathrm{IC}_{50}$ value and specific activity of NN-XIa-PLA,

\begin{tabular}{ccc}
\hline SPLA $_{2}$ & Specific activity $^{\mathbf{a}}$ & IC $_{\mathbf{5 0}}^{{ }^{\mathbf{b}}}$ \\
\hline NN-XIa-PLA & $183.6 \pm 4.6$ & $8.1 \mu \mathrm{g} / \mathrm{ml}$ \\
\hline
\end{tabular}

${ }^{a} \mathrm{nmol}$ of fatty acid released $/ \mathrm{mg}$ of protein $/ \mathrm{min}$ at $37^{\circ} \mathrm{C}$.

${ }^{\mathrm{b}} \mathrm{IC}_{50}$ value is defined as the amount of extract $(\mu \mathrm{g} / \mathrm{ml})$ required to inhibit $50 \%$ of enzyme activity in the given reaction mixture.
$120 \mathrm{nM}$ (Fig. 2). This suggests that the inhibition is independent of substrate concentration. Furthermore, in the calcium dependent activity test, it was observed that an increase in calcium concentration from 2.5 to $15 \mathrm{mM}$, increased the NN-XIa-PLA enzymatic activity in a dose dependent manner. However, while when $\mathrm{IC}_{50}$ concentration of $M$. indica extract was preincubated and then used along with varying concentrations of calcium, there was no relieve of inhibition (Fig. 3), suggesting that the inhibition by $M$. indica extract is independent on calcium concentration. All these studies show that inhibition by aqueous extract of $M$. indica is independent on substrate and calcium concentration. Furthermore, it is reported that some of the sPLA $\mathrm{P}_{2}$ inhibitors have been known to mediate displacement of catalytically essential calcium from the enzyme and consequently inhibition of enzymatic activity (Pruzanski et al. 1992). In the calcium binding experiments, it was found that

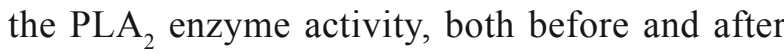
the dialysis of the enzyme inhibitor mixture, was unaltered i.e., the \% of inhibitory activity of $M$. indica extract was not decreased upon extensive dialysis, suggesting that the inhibition 


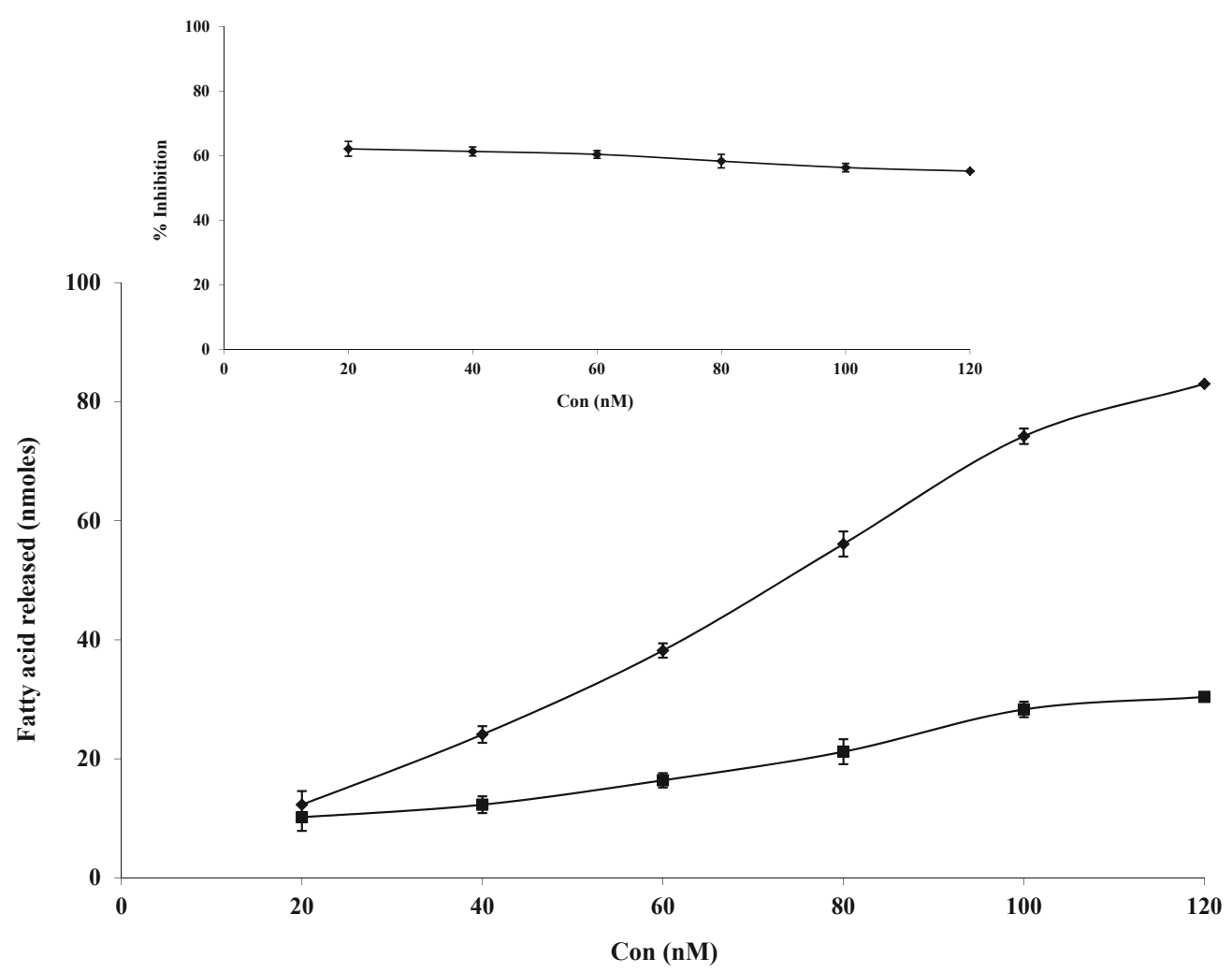

Figure 2 - Dose dependent inhibition of indirect hemolytic activity of NN-XIa-PLA by aqueous stem bark extract of $M$. indica. NN-XIa-PLA $2(4 \mu \mathrm{g})$ in $100 \mu$ of phosphate-buffered Saline (PBS) was preincubated with or without aqueous stem bark extract of $M$. indica at various concentrations $(0-40 \mu \mathrm{g} / \mathrm{ml})$. The reaction was started by adding erythrocytes, egg yolk and PBS $(1: 1: 8 \mathrm{v} / \mathrm{v})$ incubated for $10 \mathrm{~min}$ at $37^{\circ} \mathrm{C}$. The released hemoglobin in the supernatant was measured by taking absorbance at $540 \mathrm{~nm}$. The results show \pm S.E.M. for $\mathrm{n}=3$.

is irreversible, supporting the observation that inhibition by $M$. indica extract is independent on substrate and calcium concentration. These studies indicate that the inhibition could be due to direct interaction of components/molecules present in $M$. indica extract at active site residues of the $\mathrm{SPLA}_{2}$ enzyme.

NN-XIa-PLA 2 enzyme exhibited indirect hemolytic activity, which is an indirect way of measuring $\mathrm{PLA}_{2}$ activity using egg yolk and washed erythrocytes which is used as substrates. When the effect of aqueous extract of $M$. indica at different concentrations $(0-40 \mu \mathrm{g} / \mathrm{ml})$ was tested, it was found that the extract in general effectively inhibited indirect hemolytic activity up to $98 \%$ at $\sim 40 \mu \mathrm{g} / \mathrm{ml}$ concentration (Fig. 4). This in situ inhibition activity is well correlated with the inhibitory activity of the in vitro $\mathrm{PLA}_{2}$ enzyme. Therefore, the inhibition of NN-XIa-PLA $A_{2}$ activity by molecules in $M$. indica extract could be attributed to the modulation of the catalytic activity of $\mathrm{PLA}_{2}$ at the interface itself, i.e., beyond the initial steps of enzyme adsorption and activation, probably through modifications of the intermolecular organization of the membrane components. It is well known that $\mathrm{sPLA}_{2} \mathrm{~s}$ cause cell membrane asymmetry by degradation of glycerol phospholipids of the membranes (Granata et al. 2003).

Many of the inflammatory $\operatorname{sPLA}_{2} \mathrm{~s}$ induce edema (inflammatory reactions) when injected into mouse footpad as demonstrated before 


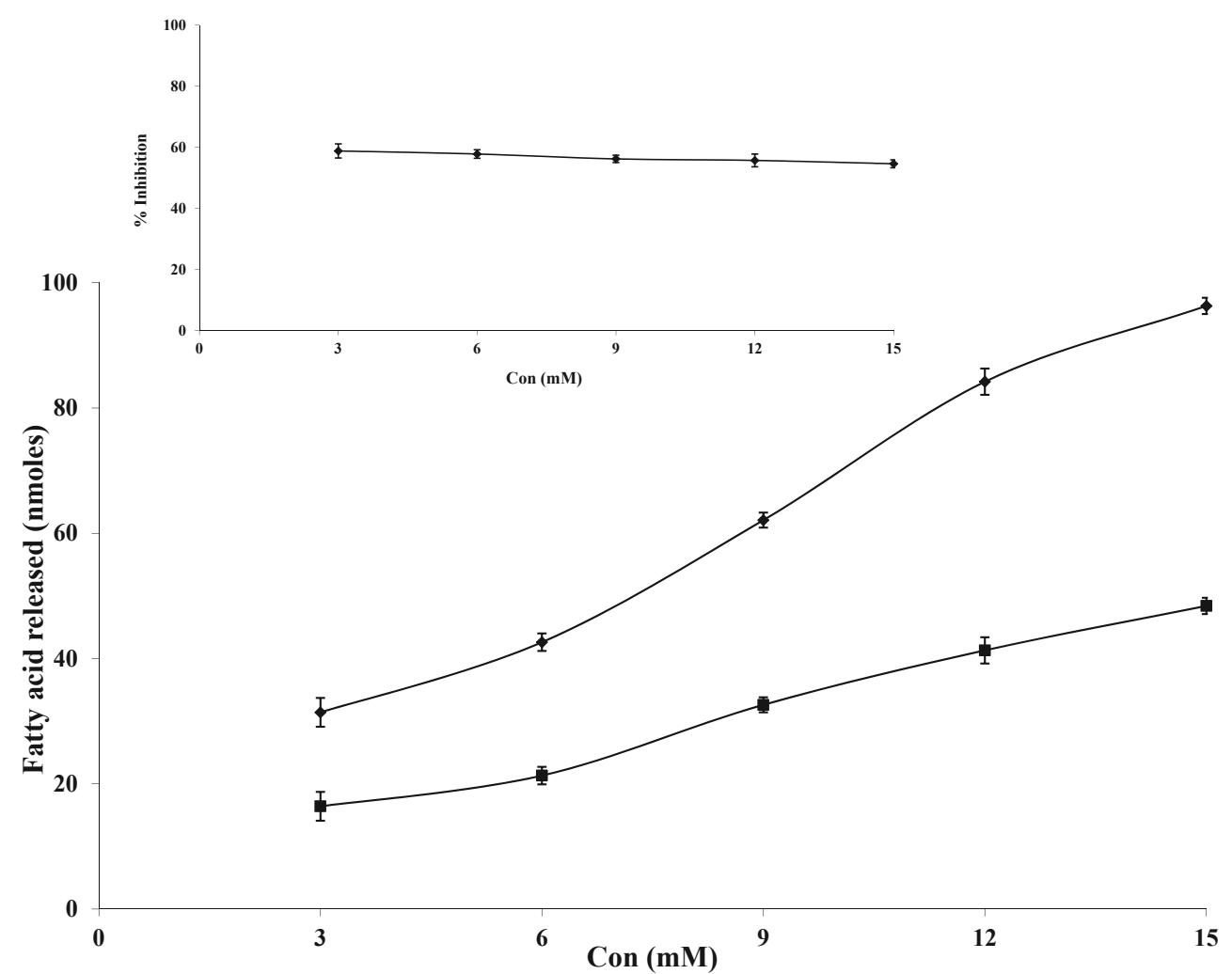

Figure 3 - Dose dependent neutralization of edema inducing activity of NN-XIa-PLA by aqueous stem bark extract of $\boldsymbol{M}$. indica. The reaction mixture $30 \mu \mathrm{l}$ containing NN-XIa-PLA 2 (6 $\mu$ gs) was incubated for $30 \mathrm{~min}$ with increasing concentration of aqueous stem bark extract $(0-50 \mu \mathrm{g} / \mathrm{ml})$ of $M$. indica. Saline $(30 \mu \mathrm{l})$ injected into the mouse foot pad served as control. Data represents \pm S.E.M for $n=3$.

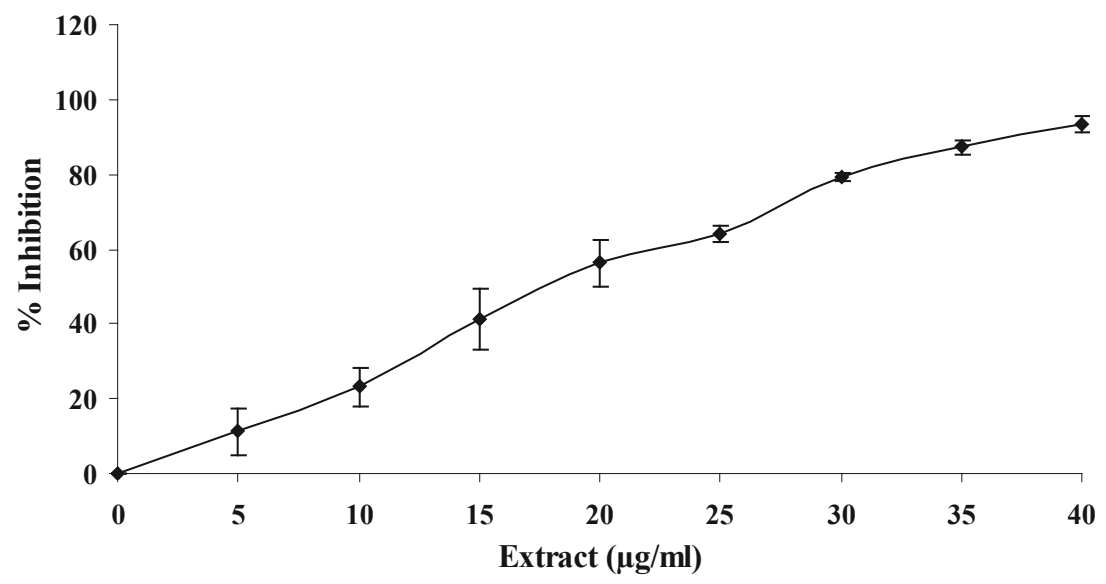

Figure 4 - Effect of substrate concentration on inhibition of NN-XIa-PLA by aqueous stem bark extract of $\boldsymbol{M}$. indica. The reaction mixture contained NNXIa-PLA ${ }_{2}$ enzyme in $0.05 \mathrm{M}$ Tri-HCl buffer $\mathrm{pH} 7.5,500 \mathrm{mM} \mathrm{CaCl}_{2}$, inhibitors, and increasing concentrations of substrate $(0-120 \mathrm{nM})$. The reaction was carried out in the absence (rhombus) and presence of $\mathrm{IC}_{50}$ concentration of extract (open square) with increasing concentration of substrate. The figure inset represents the percent of inhibition in the presence of $\mathrm{IC}_{50}$ concentration. Data represents \pm S.E.M for $\mathrm{n}=3$. 
(Vishwanath et al. 1988). Several sPLA 2 inhibitors are demonstrated to exhibit concomitant inhibition of enzyme activity and edema-inducing activity (Nanda et al. 2007, Mohamed et al. 2010). Since in our study, the aqueous extract of $M$. indica effectively inhibited the in vitro $\mathrm{SPLA}_{2}$ activity and in situ $\mathrm{SPLA}_{2}$ activity, the inhibitory potential of in vivo edema inducing activity of NN-XIa-PLA 2 was tested. The edema inducing effect of NN-XIa-PLA $(6 \mu \mathrm{g})$ was more than $175 \%$, when compared to the saline injected mice. Figure 5 shows that aqueous extract of $M$. indica at different concentrations (0$50 \mu \mathrm{g} / \mathrm{ml})$, dose dependently inhibited the edema formation, when co-injected with enzyme. In addition, $M$. indica extract at the tested dose alone did not cause edema when injected into footpads of mice. The neutralization of edema inducing activity is known to be well correlated with the in vitro enzymatic activity inhibition. It has been demonstrated that the standard extract of $M$. indica, administered orally (50-200 mg/Kg body wt.) reduced ear edema induced by arachidonic acid (AA) and phorbol myristate acetate (PMA) in mice (Garrido et al. 2006). In addition, the extract was demonstrated to inhibit the edema induced by carrageen and formalin in mice, rats and guinea-pigs (Garrido et al. 2001, Magrioti and Kokotos 2013). Furthermore, the extract has been shown to reduce the tumor necrosis factor alpha (TNF alpha) serum levels in both arachidonic acid (AA) and phorbol myristate acetate (PMA) induced models of inflammation in mice (Garrido et al. 2004). It was demonstrated that the extract inhibited the induction of $\mathrm{PGE}_{2}$ and $\mathrm{LTB}_{4}$, when it was stimulated with pro-inflammatory stimuli lipopolysaccharide-interferon gamma (LPS-IFNg) or calcium ionophore A23187 in J774 macrophage cell lines (Garrido et al. 2006). Recently, it has been shown that the aqueous stem bark extract of $M$. indica administration reduced TBARS levels and iNOS, COX-2, TNF- $\alpha$ and TNF R-2 expression in colonic tissue. A decrease in IL- 6 and TNF- $\alpha$ serum levels was also observed (Márquez et al. 2010).

Although the mechanism of action of the extract is unclear, the finding that no visible change was detected in electrophoretic pattern of $\mathrm{NN}-\mathrm{XIa}-\mathrm{PLA}_{2}$ when incubated with extracts (data not shown), excludes the proteolytic degradation as a potential mechanism (Borges et al. 2000). Furthermore, considering the results of binding

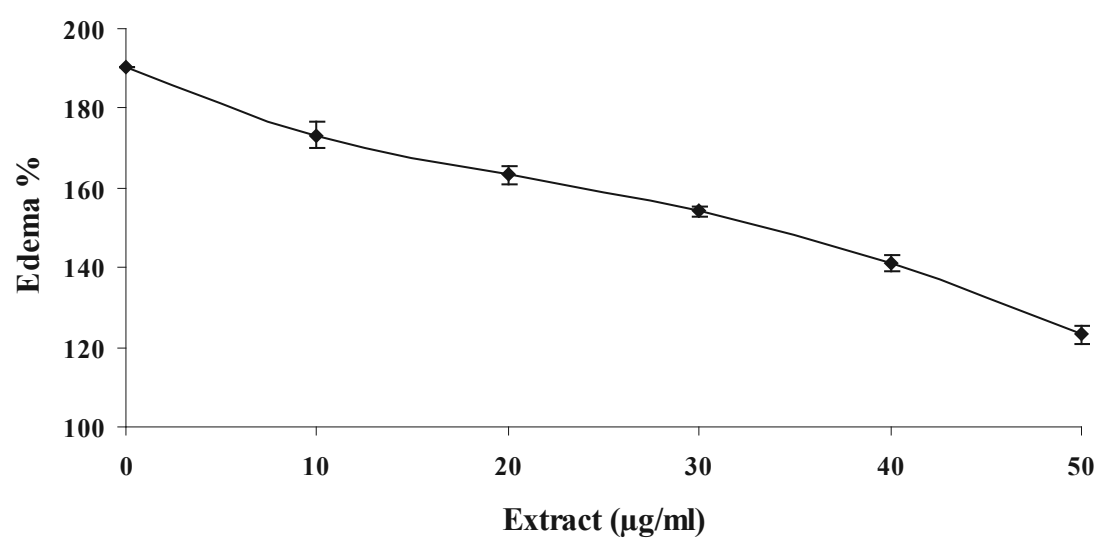

Figure 5 - Effect of calcium concentration on inhibition of NN-XIa-PLA by aqueous stem bark extract of $\boldsymbol{M}$. indica. The reaction mixture contained NN-XIa$\mathrm{PLA}_{2}$ enzyme in $0.05 \mathrm{M}$ Tri- $\mathrm{HCl}$ buffer $\mathrm{pH} 7.5$, and $0-15 \mathrm{mM} \mathrm{CaCl}_{2}$ in final volume. The reaction was initiated by adding substrate. The reaction was carried out in the absence (rhombus) and presence of $\mathrm{IC}_{50}$ concentration of extract (open square) with increasing concentration of calcium. The figure inset represents percentage inhibition in the presence of the $\mathrm{IC}_{50}$ concentration. Data represents \pm S.E.M for $\mathrm{n}=3$. 
studies, the inhibition is known to be of irreversible nature. In addition, inhibiton is observed to be of independent of substrate and calcium concentration. The most likely mechanism for anti-inflammatory activities by this extract is probably due to the direct binding of the constituents of the extract with $\mathrm{sPLA}_{2} \mathrm{~s}$ active site. The extract is known to contain a well-defined and standardized mixture of components such as polyphenols, terpenoids, steroids, fatty acids and microelements (NunezSelles et al. 2002, Shah et al. 2010), and mangiferin (20\%) being the predominant one. As with other polyphenols, the phenolic constituents of the extract like phenolic acids (Gallic acid, 3, 4 dihydroxy benzoic acid, benzoic acid) and phenolic esters (Gallic acidmethyl ester, gallic acid propylester, benzoic acid propyl ester), could also be involved in binding with $\mathrm{SLA}_{2} \mathrm{~s}$, thus bringing about inhibition (Nunez-Selles et al. 2002). In addition, the active constituents of this extract like mangiferin, amento flavone, friedelin, daucosterol and betasistosterol (Sanchez et al. 2000) seems to exhibit anti-inflammatory effect through quenching of free radicals, as they are involved in the mechanism of inflammatory process (Nanda et al. 2007, Garrido et al. 2004, 2009, Márquez et al. 2012, Vyas et al. 2012). Previously, it was demonstrated and concluded that the standardized aqueous extract of $M$. indica $\left(\mathrm{VIMANG}^{\circledR}\right.$ ) can be classified as a dual inhibitor, as it inhibits both COX and LOX pathways of arachidonate metabolism (Garrido et al. 2004). This anti-inflammatory activity of the extract was believed to be due to the powerful antioxidant activities exhibited by the constituents like phenolic compounds including mangiferin. It has been demonstrated that VIMANG ${ }^{\circledR}$ and mangiferin, exhibit inhibitory activity against synovial fluid PLA 2 activities (Garrido et al. 2004).

The aqueous stem bark extract of $M$. indica inhibiting both in vitro sPLA ${ }_{2}$ enzymatic activity and in vivo edema inducing activity of NN-XIa$\mathrm{PLA}_{2}$, suggests a strong correlation between lipolytic activity and pro-inflammatory activity inhibition. It is to be noted that this standard aqueous stem bark extract of $M$. indica has been tested in a broad set of toxicological studies with satisfactory results, including acute and subchronic toxicity, genotoxicity, and irritability and is classified as a non-toxic product (Garrido et al. 2009, Márquez et al. 2012, González et al. 2007). Thus, $M$. indica bark extract can be developed for topical application, as it is non-toxic and an effective anti-inflammatory formula contains potent antiinflammatory molecules.

\section{CONCLUSIONS}

The aqueous extract of $M$. indica effectively inhibited $\mathrm{SPLA}_{2}$ and its associated inflammatory activities. The inhibition is irreversible and also independent on substrate and calcium concentration, suggesting that the constituents of the extract might possibly directly interact to bring about inhibition. In addition, it was found that there is a strong correlation between lipolytic activity and pro-inflammatory activity inhibition. Therefore, the study suggests that the extract possesses potent antiinflammatory agents, which could be developed as a potential therapeutic agent against inflammatory related diseases. This study also substantiates their anti-inflammatory properties. Further studies on compounds responsible for the anti-inflammatory activity would be interesting, as these are highly attractive candidates for clinical development as a new class of anti-inflammatory agents.

\section{ACKNOWLEDGMENTS}

DBL thanks Jain University for the constant encouragement to progress in research. DBL acknowledge DST, Govt of India for providing the grant INT/SLP/P-007/2012, dated $15^{\text {th }}$ May, 2014. SS and DBL acknowledge the Adichunchanagiri Mahasamstana Mutt and Shikshana Trust for providing facilities in the Adichunchanagiri 
Biotechnology and Cancer Research Institute (ABCRI). We thank Balagangadharanatha Swamiji Institute for Technology (BGS-IT) and Sri Adichunchangiri College of Pharmacy for the support to carry out the research.

\section{RESUMO}

O extrato aquoso padrão da casca do caule é consumido como bebida à base de plantas e usado em formulações farmacêuticas para o tratamento de pacientes que sofrem de várias doenças em Cuba. Este estudo foi conduzido para avaliar o efeito modulador do extrato aquoso padrão da casca do caule de $M$. indica sobre o Grupo IA sPLA . Extrato de $M$. indica inibiu, de forma dependente de dose, a atividade do GIA sPLA 2 (NN-XIa-PLA $)_{2}$ com $\mathrm{IC}_{50}$ de $8,1 \mu \mathrm{g} / \mathrm{ml}$. O extrato da $M$. indica inibiu efetivamente a atividade hemolítica indireta em até $98 \%$ em uma concentração de $40 \mu \mathrm{g} / \mathrm{ml}$, e em várias concentrações $(0-50 \mu \mathrm{g} / \mathrm{ml})$, esse extrato inibiu a formação de edema de maneira dependente de dose. Quando examinado como uma função de aumento de concentrações de substrato e cálcio, não houve diminuição do efeito inibitório sobre GIA sPLA . Adicionalmente, a inibição foi irreversível, como evidenciado em estudos de ligação. Foi observado que o extrato aquoso da $M$. indica inibe efetivamente sPLA $_{2}$ e está associado a atividades anti-inflamatórias, o que corrobora suas propriedades anti-inflamatórias. A inibição pode ser devida a uma interação direta dos componentes presentes no extrato com a enzima $\mathrm{sPLA}_{2}$. Mais estudos sobre o entendimento dos principais constituintes responsáveis pela atividade anti-inflamatória seriam de interesse para o desenvolvimento destes componentes como potenciais agentes anti-inflamatórios.

Palavras-chave: fosfolipase $A_{2}$ secretória, anti-inflamatório, pró-inflamatório, inibição, drogas, plantas.

\section{REFERENCES}

BALSINDE J, BALBOA MA, INSEL PA AND DENNIS EA. 1999. Regulation and inhibition of phospholipase $\mathrm{A}_{2}$. Annu Rev Pharmacol Toxicol 39: 175-189.

BHAT MK AND GOWDA TV. 1989. Purification and characterization of a myotoxic phospholipase $\mathrm{A}_{2}$ from Indian cobra (Naja naja naja) venom. Toxicon 27: 861-873.

BOMALASKI JS AND CLARK MA. 1993. Phospholipase $\mathrm{A}_{2}$ and arthritis. Arthritis Rheum 36: 190-198.
BOMAN HG AND KALETTA U. 1957. Chromatography of rattle snake venom, a separation of three phosphodiesterases. Biochim Biophys Acta 24: 619-631.

BORGES MH ET AL. 2000. Effects of aqueous extract of Casearia sylvestris (Flacourtiaceae) on actions of snake venom and bee venoms and on activity of phospholipase $\mathrm{A}_{2}$. Comp Biochem Physiol Biochem Mol Biol 127: 21-30.

BURKE JE AND DENNIS EA. 2009. Phospholipase $\mathrm{A}_{2}$ structure/function, mechanism, and signaling. J Lipid Res 50: S237-S242.

Chalbot S, Zetterberg H, Blennow K, Fladby T, ANDREASEN N, GRUNDKE-IGBAL I AND IGBAL K. 2011. Blood-cerebrospinal fluid barrier permeability in Alzheimer's disease. J Alzheimers Dis 25: 505-515.

CHOPRA RN, NAYAR SL AND CHOPRA IC. 1956. Glossary of Indian medicinal plants, CSIR publication, New Delhi, $330 \mathrm{p}$.

COE FG AND ANDERSON GJ. 1996. Screening of medicinal plants used by the Garı'funa of eastern Nicaragua for bioactive compounds. J Ethnopharmacol 53: 29-50.

DAVIDSON FF, DENNIS EA, POWELL M AND GLENNEY JR JR. 1987. Inhibition of Phospholipase $A_{2}$ by 'lipocortins' and calpactins. An effect of binding to substrate phospholipids. J Biol Chem 262: 1698-1705.

DE LUCA D, MinuCCI A, COGO P, CAPOLUONGO ED, CONTI G, Pietrini D, CARnielli VP AND PiAstra M. 2011. Secretory phospholipase $A_{2}$ pathway during pediatric acute respiratory distress syndrome: a preliminary study. Pediatr Crit Care Med 12: e20-e24.

DESSì M, NOCE A, BERTUCCI P, MANCA DI VILLAHERMOSA S, Zenobi R, CAStagnola V, AdDessi E AND Di DANIELE N. 2013. Atherosclerosis, Dyslipidemia, and Inflammation: The Significant Role of polyundaturated Fatty acids. ISRN Inflamm 2013: 191823.

DHANANJAYA BL, ZAMEER F, GIRISH KS AND D'SOUZA CJ. 2011. Anti-venom potential of aqueous extract of stem bark of Mangifera indica L. against Daboia russelii (Russell's viper) venom. Indian J Biochem Biophys 48(3): 175-183.

DiAZ BL AND ARM JP. 2003. Phospholipase A. Prostaglandins Leukot Essent Fatty Acids 69: 87-97.

Doley R, ZHOU X AND KINI RM. 2010. Snake Venom Phospholipase $\mathrm{A}_{2}$ Enzymes. In Handbook of Venoms and Toxins of Reptiles; Mackessy SP Ed., CRC Press: Boca Raton, FL, USA, p. 173-205.

FAROOQUI AA, LITSKY ML, FAROOQUI T AND HORROCKS LA. 1999. Inhibitors of intracellular phospholipase $A_{2}$ activity: their neurochemical effects and therapeutical importance for neurological disorders. Brain Res Bull 49: 139-153.

GARrido G, GonZÁlez D, DELPORTE C, BACKHOUSE N, QUINTERO G, NÚÑEZ-SELlÉS AJ AND MORALES MA. 2001. Analgestic and anti-inflammatory effects of Mangifera indica L. Extarct (Vimang). Phytother Res 15: 18-21. 
GARrido G, GONZÁlez D, LEMUS Y, DELPORTE C AND DELGADO R. 2006. Protective effects of a standard extarct of Mangifera indica L. (VIMANG) against mouse ear edemas and its inhibition of eicosanoid production in J7774 murine macrophages. Phytomedicine 13: 412-418.

GARRIDO G, GONZALEZ D, LEMUS Y, GARCIA D, LODEIRO L, Quintero G, Delporte C, NunEZ-SElles AJ AND DELGADO R. 2004. In vivo and in vitro anti-inflammatory activity of Mangifera indica L. extract (VIMANG). Pharmacol Res 50: 143-149.

GARrido G, RodeIro I, HERNÁNDEZ I, GARCÍA G, PÉREZ G, Merino N, NúÑEZ-Sellés A AND Delgado R. 2009. In vivo acute toxicological studies of an antioxidant extract from Mangifera indica L. (Vimang). Drug Chem Toxicol 32: 53-58.

Granata F, BALESTRIERI B, PETRAROLI A, GiANNATTASIO G, MARONE G AND TRIGGiani M. 2003. Secretory phospholipase $\mathrm{A}_{2}$ as multivalent mediators of inflammatory and allergic disorders. Int Arch Allergy Immunol 131: 153-163.

Guevara GM, TAmayo BD, Gonzalez LS, Paez BE, OCEguera J AND NunEZ-SElles AJ. 1998. Ethnopharmacologic study of Mangifera indica L. extract (QF-808). Abstract of $1^{\text {st }}$ International congress pharmacology`98, ed., ORTOP, La Habana, p. 45.

GONZÁLEZ JE ET AL. 2007. Lack of in vivo embryotoxic and genotoxic activities of orally administered stem bark aqueous extract of Mangifera indica L. (Vimang). Food Chem Toxicol 45: 2526-2532.

KIM HP, SON KH, CHANG HW AND KANG SS. 2004. Anti-inflammatory plant flavonoids and cellular action mechanism. J Pharmacol Sci 96: 229-245.

KINI RM. 2003. Excitement ahead: Structure, function and mechanism of snake venom phospholipase $\mathrm{A}_{2}$ enzymes. Toxicon 42: 827-840.

LOMOnTE B, ANGUlo Y, SASA M AND GUTIÉRREZ JM. 2009. The phospholipase $A_{2}$ homologues of snake venoms: Biological activities and their possible adaptive roles. Protein Pept Lett 16: 860-876.

LOWRY OH, ROSEBROUGH NJ, FARR AL AND RANDALL RJ. 1951. Protein measurement with the Folin phenol reagent. J Biol Chem 193: 265-275.

Magrioti V And KoKotos G. 2013. Phospholipase $A_{2}$ inhibitors for the treatment of inflammatory diseases: a patent review (2010-present). Expert Opin Ther Pat 23: 333-344.

MAKARE N, BODHANKAR S AND RANGARI V. 2001. Immunomodulatory activity of alcoholic extract of Mangifera indica L. in mice. J Ethnopharmacol 78: 133-137.

MALLAT Z, LAMBEAU G AND TEDGUI A. 2010. Lipoproteinassociated and secreted phospholipases $\mathrm{A}_{2}$ in cardiovascular disease: roles as biological effectors and biomarkers. Circulation 122: 2183-2200.

MÁrquez L, GARcía-Bueno B, MADrigal JL AND LEZA JC. 2012. Mangiferin decreases inflammation and oxidative damage in rat brain after stress. Eur J Nutr 51: 729-739.

MÁrQUEZ L, PÉREZ-NIEVAS BG, GÁRATE I, GARCÍA-BUENO B, MADRIGAL JL, MENCHÉN L, GARRIDO G AND LEZA JC. 2010. Anti-inflammatory effects of Mangifera indica L. Extract in a model of colitis. World J Gastroenterol 16: 4922-4931.

Meyer MC, Rastogi P, BeCKett CS AND MCHOWAT J. 2005. Phospholipase $A_{2}$ inhibitors as potential antiinflammatory agents. Curr Pharm Des 11: 1301-1312.

MOHAMED R, DHARMAPPA KK, TARANNUM S, JAMEEL NM, KANNUM SA, ASHRAFUlla HS, RAI L, SOUZA CJ, SHEKHAR MA AND VISHWANATH BS. 2010. Chemical modification of ascorbic acid and evaluation of its lipophilic derivatives as inhibitors of secretory phospholipase A(2) with anti-inflammatory activity. Mol Cell Biochem 345: 69-76.

Moses GS, Jensen MD, LUE LF, WALKer DG, SUN AY, SIMONYI A AND SUN GY. 2006. Secretory PLA 2 -IIA: a new inflammatory factor for Alzheimer`s diseases. J Neuroinflammation 3: 28.

NANDA BL, NATARAJU A, RAJESH R, RANGAPPA KS, SHEKAR MA AND VISHWANATH BS. 2007. PLA mediated arachidonate free radicals: PLA $_{2}$ inhibition adn neutralization of free radicals by anti-oxidants - a new role as anti-inflammatory molecule. Curr Top Med Chem 7(8): 765-777.

NARENDRA SHARATH CHANDRA JN, PONNAPPA KC, SADASHIVA CT, PRIYA BS, NANDA BL, GOWDA TV, VISHWANATH BS AND RANGAPPA KS. 2007. Chemistry and structural evaluation of different phospholipase $\mathrm{A}_{2}$ inhibitors in arachidonic acid pathway mediated inflammation and snake venom toxicity. Curr Top Med Chem 7(8): 787-800.

NEVALAINEN TJ, CARDOSO JC AND RIIKONEN PT. 2012. Conserved domains and evolution of secreted phospholipases A(2). FEBS J 279: 636-649.

NuneZ-SElles AJ, Velez HT, Aguero J, GONZALEZ J, NADDEO F, DE SimONE F AND RASTRELli L. 2002. Isolation and quantitative analysis of phenolic antioxidants, free sugars, and polyols from Mango (Mangifera indica L.) stem bark aqueous decoction used in Cuba as a nutritional supplement. J Agric Food Chem 50: 762-766.

OJEWOLE JA. 2005. Antiinflammatory, analgesic and hypoglycemic effects of Mangifera indica linn. (Anacardiaceae) stem-bark aqueous extract. Methods Find Exp Clin Pharmacol 27: 547-554.

PRUZANSKI W, GREENWALd RA, STREet IP, LALIBERTE F, STEFANSKI E AND VADAS P. 1992. Inhibition of enzymatic activity of Phospholipases $A_{2}$ by minocycline and doxycycline. Biochem Pharmacol 44: 1165-1170.

ROSENSON RS, FRASER H, TRIAS J AND HISLOP C. 2010. Varespladib methyl in cardiovascular disease. Expert Opin Investig Drugs 19: 1245-1255. 
RUDRAMMAJI LM AND GOWDA TV. 1998. Purification and characterization of three acidic, cytotoxic phospholipase $\mathrm{A}_{2}$ from Indian cobra (Naja naja) venom. Toxicon 36: 921932.

SAnchez GM, Re L, GiUliani A, Nunez-Selles AJ, DAVISON GPAND LEON-FERNANDEZ OS. 2000. Protective effects of Mangifera indica L. extract, mangiferin and selected antioxidants against TPA-induced biomolecules oxidation and peritoneal macrophage activation in mice. Pharmacol Res 42: 565-573.

SCOTT KF, SAJINOVIC M, HEIN J, NiXdorF S, GALETTIS P, LiauW W, DE SOUZA P, DONG Q, GRAHAM GG AND RUSSELL PJ. 2010. Emerging roles for phospholipase $A_{2}$ enzymes in cancer. Biochimie 92: 601-610.

Shah KA, PATEl MB, PATEl RJ AND PARMAR PK. 2010. Mangifera indica (mango). Pharmacogn Rev 4: 42-48.

Slesser AA, Bhangu A, BOWER M, GOLdin R AND TEKKIS PP. 2013. A systemic review of anal squamous cell carcinoma in inflammatory bowel disease. Surg Oncol 22: 230-237.

SPRINGER DM. 2001. An update of inhibitors of human 14 kDa type II s- PLA 2 in development. Curr Pharm Des 7: 181-198.

Sun GY, XU J, JENSEN MD AND SIMONYI A. 2004. Phospholipase $A_{2}$ in the central nervous system: implications for neurodegenerative diseases. J Lipid Res 45: 205-213.
VADAS P AND PRUZANSKI W. 1984. Role of extracellular phospholipase $\mathrm{A}_{2}$ in inflammation. Adv Inflam Res 7: 5159.

VANE JR AND BOTTING RM. 1998. Anti-inflammatory drugs and their mechanism of action. Inflamm Res 47: 78-87.

VISHWANATH BS, FAWZY AA AND FRANSON RC. 1988. Edema inducing activity of phospholipase $\mathrm{A}_{2}$ purified from human synovial fluid and inhibition by aristolochic acid. Inflammation 12: 549-561.

VISHWANATH BS, KINI RM AND GOWDA TV. 1987. Characterization of three edema inducing phospholipase $\mathrm{A}_{2}$ enzymes from habu (Trimeresurus flavovoridis) venom and their interaction with the alkaloid aristolochic acid. Toxicon 25: 501-515.

VyAS A, SYEDA K, AHMAD A, PADHYE S AND SARKAR FH. 2012. Perspectives on medicinal properties of mangiferin. Mini Rev Med Chem 12: 412-425.

Wright GW, OOL CE, Weiss J AND Elsbach P. 1990. Purification of a cellular (granulocyte) and extracellular (serum) phospholipase $\mathrm{A}_{2}$ that participate in the destruction of Escherichia coli in a rabbit inflammatory exudates. J Biol Chem 26: 6675-6681.

YAMAKAWA MM AND HOKAMA NZ. 1976. Fractionation of Sakishima habu (Elegans T) venom and lethal hemorrhagic and edema forming activity of the fractions. In: Ohsaka A, Hayashi K and Sawai Y (Eds), Animal, plant and microbial toxins, Plenum Press, New York 1: 97. 